\title{
Christopher Hood \& Ruth Dixon: A Government that Worked Better and Cost Less? Evaluating Three Decades of Reform and Change in UK Central Government
}

Oxford University Press, 2015, 229 sider

Anmeldt af Steen Juul Hansen, docent, VIA University College

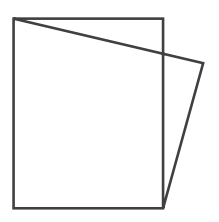

På omslaget til bogen er der et billede fra en væg i templet i Karnak (Luxor) i ÆEgypten. Det viser en kalender, hvor der er registreret festivaler samt størrelsen af de ofringer, der er foretaget på den enkelte festival. Kalenderen er fra 1450 før Kristi - ca. 3500 år gammelt. Billedet er taget af Ruth Dixon, en af forfatterne til bogen. Det skal minde om, at nogle administrative procedurer og registreringer er mere varige end andre. Med dette billede er temaet for bogen slået an, og det antydes, at New Public Management som ramme for modernisering af den offentlige sektor nok ikke sætter sig samme varige spor, som kalenderen i Karnak. Bogen er en evaluering af de seneste 30 års reformer i den offentlige sektor $\mathrm{i}$ Storbritannien. Forfatterne Christopher Hood og Ruth Dixon har fulgt udviklingen i den offentlige sektor i Storbritannien i mange år. Hood har været med til at give reformtiltagene i den offentlige sektor i den vestlige verden (fra midten af 1980'erne og frem) betegnelsen New Public Management - NPM. Hvorfor er bogen så interessant i en dansk sammenhæng? Fordi NPM i omfattende grad har præget udviklingen af den offentlige sektor i Danmark siden Poul Schlüters moderniseringsredegørelse i 1983. Skiftende regeringer har forsøgt at reformere og "modernisere" den offentlige sektor efter de opskrifter, som NPM foreskriver. Det drejer sig kort fortalt om markedsgørelse af den offentlige sektor, management, mål- og resultatstyring samt anvendelse af IT. Det er klart, at det er relevant at vide, om et så dominerende styringsparadigme virker i virkelighedens verden. Folkedomstolen har længe dømt NPM ude. Det samme har de velfærdsprofessionelle, som skal føre reformerne ud i praksis og leve med den praksis, som reformerne skaber. Det er folkeskolelærerne, sygeplejersker, socialrådgivere, 
læger mm. Men har folkedomstolen og de velfærdsprofessionelle nødvendigvis ret? Det giver bogen et veldokumenteret svar på. Bogens korte svar er: Nej, NPM virker ikke. Bogens argumentation herfor foldes ud i det følgende.

Bogen starter med at fremhæve, at den offentlige sektor de seneste 30 år har været udsat for gentagne reformer med det klare formål at mindske udgifterne til den offentlige sektor samtidig med, at den skulle fungere bedre for borgere og brugere. "Creating a Government that Works Better and Costs Less". Bogen evaluerer, om reformbestræbelserne rent faktisk er lykkedes, så vi som borgere og brugere har fået mere service for færre penge. Storbritannien tjener som kritisk case i analysen. Bogens analyser viser, at reformerne ikke holder, hvad de lover. De gennemførte reformer har haft den modsatte effekt - med stigende offentlige udgifter og dårligere offentlig service til følge.

Hood og Dixon undrer sig over, hvad de kalder en bemærkelsesværdig mangel på evidens for, at de gennemførte reformer har virket. Det er bemærkelsesværdigt, fordi NPM foreskriver dokumentation og gennemsigtighed i den offentlige sektor. Hvorfor skulle der gå 30 år, før nogen gennemførte en systematisk evaluering af effekterne af NPM? NPM og de tilhørende reformer er blevet flittigt debatteret og kommenteret. De analyser, der er blevet gennemført har imidlertid mere haft karakter af retorik og ideologi end af egentlige analyser af administrative data. Reformerne har været drevet af forventninger til resultaterne af reformerne og af processerne i forbindelse med reformernes tilblivelse og gennemførelse. Reformerne har ikke været drevet af viden om, hvad der virker. Diskussionerne om effekterne af NPM har derfor været præget af "bragesnak", efter forfatternes mening.

Bogen er på 229 sider, fordelt på et kort forord og 9 kapitler. Den er en afrapportering af et evalueringsprojekt om effekterne af NPM, som har været længe undervejs - tre år. Bogens form og indhold er præget af, at der er tale om en videnskabelig afrapportering.

Kapitel 1 opridser problemstillingen for evalueringen - har NPM medført en bedre og billigere offentlig sektor? Herefter følger en kort gennemgang af analysens konklusioner samt en kort gennemgang af de enkelte kapitler i bogen. Forfatterne afgrænser NPM til at omfatte tre temaer: 1) Managementreformer, 2) øget anvendelse af IT og 3) anvendelse af spin i den offentlige sektor i forbindelse med gennemførelse af reformerne. I den forbindelse citerer forfatterne en spindoktor for at have sagt, at det ikke betyder noget, hvor god man i virkeligheden er. Det betyder noget, hvordan du kommunikerer, hvor god du er.

Kapitel 2 giver en kort beskrivelse af udviklingen i den statslige administration i Storbritannien i de seneste 30 år. Kapitlet beskriver den kontekst, NPM-reformerne er blevet gennemført i.

Kapitel 3 beskriver datagrundlaget for evalueringen. Forfatterne undrer sig over, at det ikke er muligt at skabe et sammenhængende kvantitativt datasæt for hele perioden. Regeringen har løbende ændret den administrative registrering af resultaterne af dens politik. Så forfatterne har i vid udstrækning selv måttet konstruere og kombinere data, der kan bruges i evalueringen. Og de har måttet trække på mange forskellige kilder for at belyse resultaterne af NPM.

I kapitlerne 4, 5 og 6 opgøres udviklingen i omkostningerne til centraladministrationen samt kvaliteten af den offentlige administration. De tre kapitler udgør kernen i evalueringen, fordi de giver svaret på, om NPM har medført en bedre fungerende offentlig sektor til færre penge. I kapitel 7 og 8 diskuteres resultaterne af evalueringen. Bogen afsluttes med en god opsamling.

Uanset om man er for eller imod NPM, så er det positivt, at der med denne bog foreligger evidens for, om NPM holder, hvad det lover. Godt nok er evalueringen foretaget i Storbritannien, men jeg er overbevidst om, at resultatet kan overføres til en dansk kontekst. Hvorfor skulle det ikke kunne det? NPM har også været et dominerende styringsparadigme i Danmark, hvor vi har gennemført mange af de samme reformer som i Storbritannien. Og den offentlige sektor i Storbritannien har mange lighedstræk med den danske. Evalueringen betyder, at diskussionen for og imod NPM ikke længere behøver at være præget af følelser og ideologi, men kan baseres på evidens.

Det er ikke kun i Storbritannien, at man diskuterer nytten af NPM som styringsparadigme. Det gør man også i Danmark - og i de nordiske lande i øvrigt. Fra politisk hold begynder man så småt at tage afstand fra NPM. I Danmark taler man om tillidsreform, og om at man skal have mere ledelse med faglig substans og mindre management i den offentlige sektor. De velfærdsprofessionelles faglighed og professionelle råderum skal genetableres. Jeg tror ikke, at det kommer til at ske fra den ene dag til den anden. Dertil er NPM et alt for dominerende og institutionaliseret styringsparadigme. Bogen A Government that Worked Better and Cost Less er et rigtig nyttigt bidrag til den fortsatte diskussion om, hvordan man skal styre den offentlige sektor med de bedste resultater til følge. 